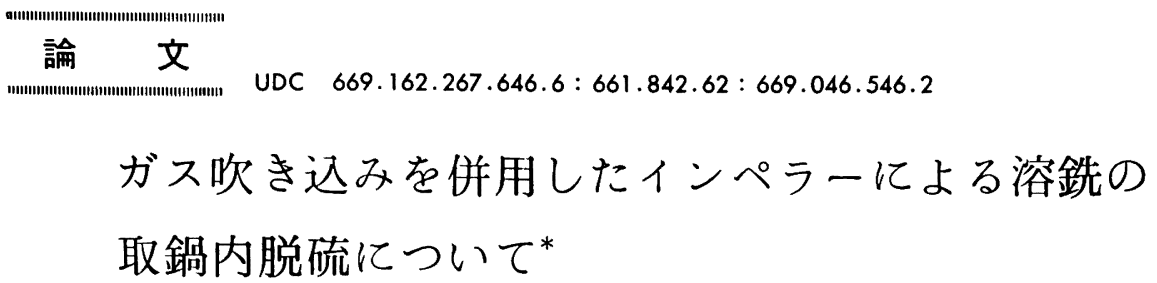

\author{
中西恭二 $* *$. 別所永康 ${ }^{* * *}$. 高田至康 ${ }^{* * *}$. 江島须夫 ${ }^{* * *}$ \\ 久我正昭 $* * * *$ 香月淳一 $* * * *$. 川名昌志 $* * * *$
}

\title{
On the Desulfurization of the Molten Metal in an Open Ladle Stirred by an Impeller Modified by Gas Injection
}

\author{
Kyoji Nakanishi, Nagayasu Bessho, Yoshiyasu TAkada, Akio EJima, \\ Masaaki KugA, Junichi KAtsuki, and Masashi KawanA
}

\begin{abstract}
Synopsis :
In order to enhance the dispersion of desulfurizing agents into hot metal, the injection of nitrogen gas has been used together with the revolutional stirring by an impeller of a gate type. At the both ends of the impeller, a nozzle is embedded and used for the injection of nitrogen gas into hot metal toward the direction opposite to the movement of the impeller.

Water model experiments show that the gas injected efficiently breaks up a cone shaped agglomerate of desulfurizing agents at the bottom of the rotational vortex formed around the impeller shaft and makes it disperse homogeneously into the bath. This suggests that the chemical efficiency of desulfurization will be improved to a greater extent than that without the gas injection.

The plant scale equipment has been constructed to desulfurize $60 \mathrm{t}$ of hot metal in a ladle. Under the condition of $77 \mathrm{rpm}$ in revolution rate and $3 \mathrm{Nm}^{3} / \mathrm{min}$ of nitrogen gas, sulfur content of $0.05 \%$ is reduced to $0.012 \%$ after the treatment of $11 \mathrm{~min}$ with calcium carbide of $3 \mathrm{~kg}$ ( $75 \%$ in purity) per ton of hot metal.

The observed rate of desulfurization is reasonably interpreted in terms of the rate controlled by sulfur transfer in hot metal.
\end{abstract}

\section{1. 緒言}

快削鋼，珪素鎾などの特殊鋼を別にすれれば，不純物と して鋼に含まれる硫黄は, 品質を損ら有害元素である. とくに近年，ライン・ハイプ材の水素誘起割れ，あるい は厚板材のラメラー・テャー (lamellar tear) など硫化物 系介在物に起因した欠陷が問題視されており，極低硫材 の要求はますます緟しくなってきている.

かかる䞶勢から，高炉と転炉による大量生産プロ七ス では，高炉溶銑の炉外脱硫設備が不可欠となつている. このような脱硫設備として，今日まで種々のプロセスが 開発されている1) -4). 当社, 千葉製鉄所においても, 取 鍋溶銑を対象にした脱硫装置として NP 法 (Nitrogen
Propeller Process) を開発し，カルシウム・カーバイド $\left(\mathrm{CaC}_{2}\right)$ 系脱硫剤を用いて，实用化している.

NP 法の原理は, 従来の門型インペラーによる回転摫 拌に加觉て，溶銑中に浸漬したインペラー両端部から窒 素ガスを回転方向と逆向きに吹き込むものであり，つぎ の 2 つの特長を有する.

（1）インペラーの回転摫找により，浴面中央部には 凹みを生じる、固形脱硫剤は，この凹み部に集積した後, 溶銑中に巻き込まれるが，その分散の度合は必ずしも十 分とはいえないＮP 法では窒素ガスによる攪拌の併用 により，脱硫剤の分散を強化することができる．

（2）㹂汼に使用した窒素ガスは，溶銑中から離脱し た後，浴面上の雾囲気を 不活性に 保持するのにも役立

* 昭和 52 年 4 月本会譜演大会にて発表 昭和 52 年 11 月 22 日受付 (Received Nov. 22, 1977)

** 川崎製鉄 (株) 技術研究所工博 (Research Laboratories, Kawasaki Steel Corp., 1 Kawasaki-cho Chiba 280)

*** 川崎製鉄 (株) 技術研究所 (Research Laboratories, Kawasaki Steel Corp.)

**** 川崎彆鉄 (株) 千葉製鉄所 (Chiba Works, Kawasaki Steel Corp.) 
つ.すなわち大気との反応による $\mathrm{CaC}_{2}$ の酸化，あるい は脱硫生成物, $\mathrm{CaS}$ の再酸化による復硫などを防止する ことができる。

本論文では，まず混合特性の把握を目的に実施した水 モデル実験の結果を述べ，つぎにこれにもとついて製作 した実機の特長を述べる，つついて現場規模での脱硫性 能を明らかにした後，それらの結果を速度論的に検討す る.

\section{2. 水モデル実験}

$60 \mathrm{t}$ 溶銑鍋を対象にした実設備を約 $1 / 5$ に縮尺した 水モデル実験装置を試作して，NP プロセスに打混

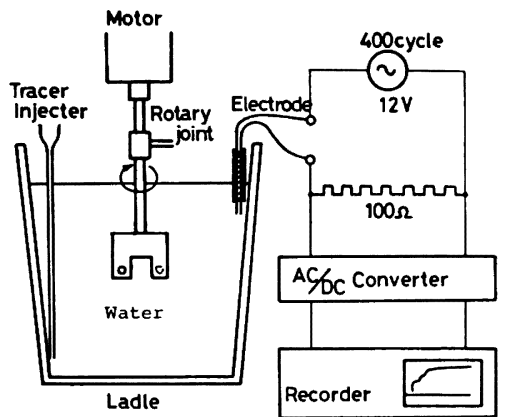

Fig. 1. The setup of the water model together with the measuring system of the tracer dispersion.

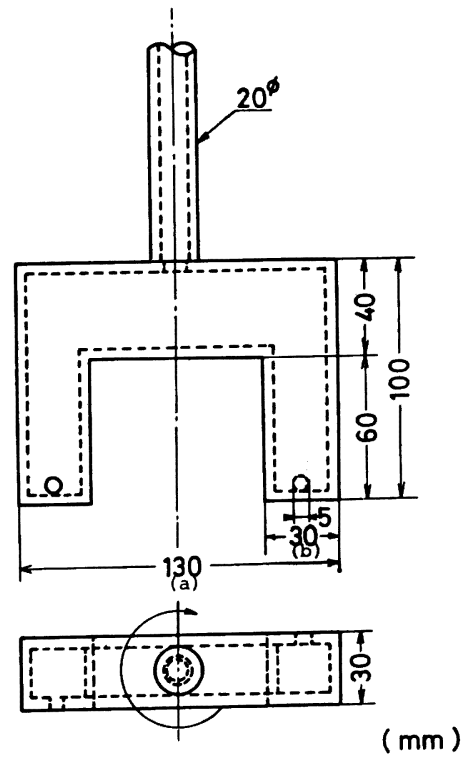

Fig. 2. NP impeller user for the cold model experiment.
合特性および浴のフローパターンを調べた。

\section{$2 \cdot 1$ 混合特性}

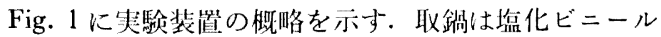
諘で底部内径 $400 \mathrm{~mm}$, 上部内径 $438 \mathrm{~mm}$ および高さ 465 $\mathrm{mm}$ である.これに溶銑を想定して，深さ $340 \mathrm{~mm}$ の 位置まで 451 の水を満たした。丰験に供したインペラ 一の代表例を Fig. 2 に示す. 形状は門型であり，両端 部に径 $5 \mathrm{~mm}$ の窒素ガス吹き込み口を有する．窒素ガ スはロータリー・ジョイントを介して, シャフト内部の 管路に吹き込まれ，上述の開孔部より水中に吹き出す.

混合特性はトレーサー応答曲線を求めることにより測 定したが，その添加方法は目的に応じて，つぎの 2 方法 を用いた。

（1）均一混合時間の測定に際しては，20\% $\mathrm{KCl}$ 水 溶液を約 $5 \mathrm{cc}$ 注入器より取鍋底に添加し, 均一濃度に 至る応答曲線を, 浴面直下に浸漬した電極により, 電気 伝導度の変化として捉えた。

（2）混合時間におよぼす窒素ガス併用効果を観察す る場合は, 固形脱硫剤 $\mathrm{CaC}_{2}$ と溶銑中の $\mathrm{S}$ との反応を 想定し，トレーサーとして KCl を付着した発泡アルミ ナ（径 2〜2.8 mm, 比重 0.51) を浴面上に添加し, 濃 度検出位置を鍋底とした。

均一混合時間, $\theta$ はトレーサー応答曲線が均一混合後 の濃度の $\pm 5 \%$ のバンド内に収束するまでの時間と定 我した.

インペラーの回転速度, 浸漬深さなどを変えて, 一連 のトレーサー実験を行ない，それぞれの混合時間を求め た. KRAMERS ら5) は混合時間 $\theta$ がインペラーの回転速 度 $N(\mathrm{rps})$ に反比例することを見出し，両者の積 $N \theta を$

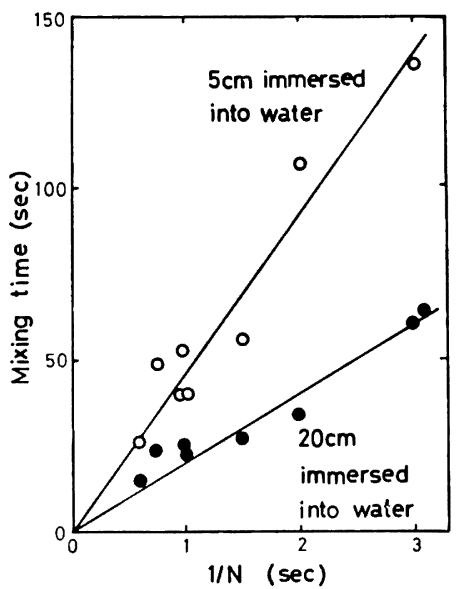

Fig. 3. Relationship between mixing time and inversed values of revolution rate. 


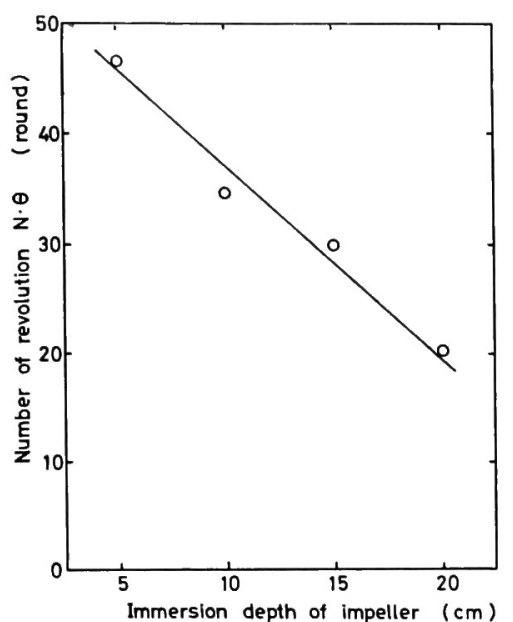

Fig. 4. Relationship between number of revolution required for perfect mixing and immersion depth of the impeller.

混合に必要な回転数とし, 攪拌器の特性值と定めた。 $N \theta$ が小さいほど効率のよい攪找器といえる.

本実験結果の 2 例について上述の関係を検証すれば Fig. 3 となり， $\theta$ と $1 / N$ の直線関係がよく成立つてい る. そこで所定浸漬深さで行なつた一連の実験から $N \theta$ を求め，これと浸漬深さの関係をみ机ば Fig. 4 となる. インペラー浸漬深さが増すにつれ $N \theta$ は減少するが, こ れは浸漬深さの増大に伴い, 取鍋上部と下部の液がイン ペラーに同等に吸い込まれ，混合しながら吐出されるた

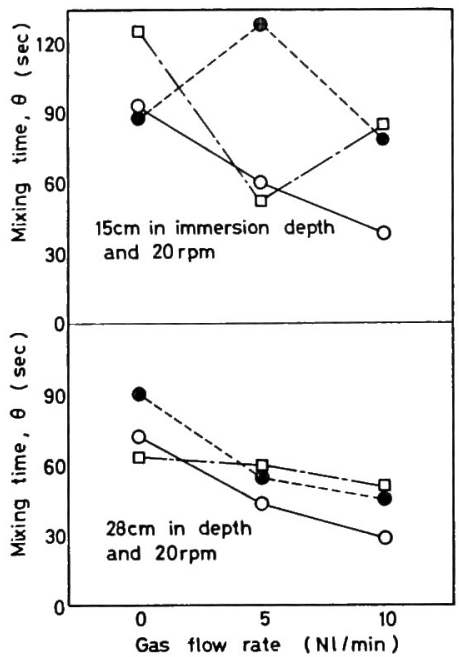

Fig. 5. Time required for perfect mixing of $\mathrm{KCl}$ coated on hollow alumina balls which are floating on the surface of the bath and are assumed as desulfurizing agents.
め㩭拌効率が向上するものと考光ら机る。

\section{$2 \cdot 2$ 混合時間におよぼす窒素ガス併用効果}

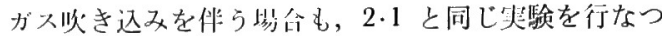
てみたが混合時間に拈よぼずス吹き込みの效果はほと んど認められなかつた。

そこで，ここでは溶銑と $\mathrm{CaC}_{2}$ 間の反応を想定して， $2 \cdot 1$ で述べたトレーサー添加法（2）によつた. 発泡ア ルミナは, $\mathrm{KCl}$ 飽和水溶液中に数時間浸した後, 引上 げ㓓燥させて头験に供した。

予備実験によれば，インペラー回転速度が大の時, あ るいはインペラーがスラグーィタル界面にまたがる時に
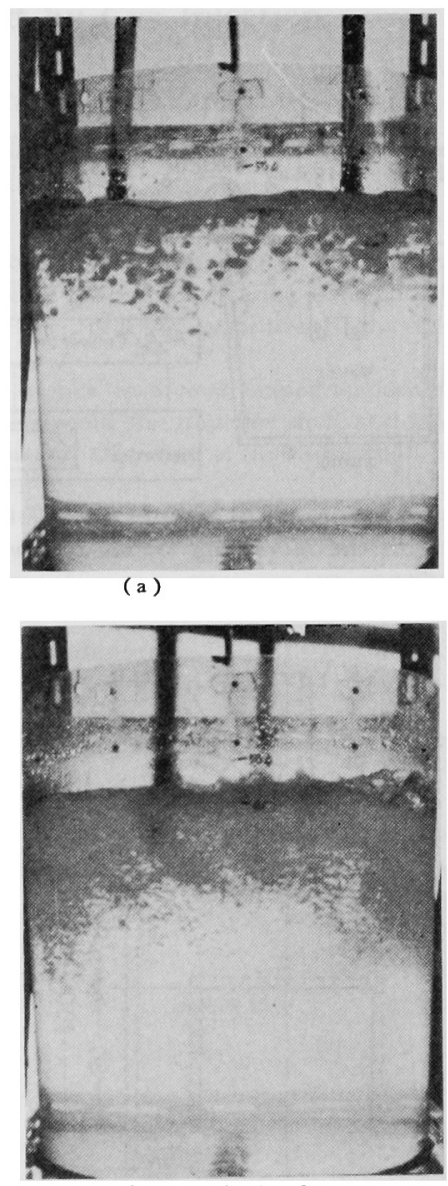

(b) $30 \mathrm{Nl} / \mathrm{min}$ of $\mathrm{N}_{2}$

Photo. 1. Influence of gas injection on the dispersion of liquid paraffin, where the impeller is rotated at the rate of $80 \mathrm{rpm}$ and is immersed into the depth of $5 \mathrm{~cm}$; a fine dispersion of the slag agent is attained by the injected gas (b), which shows a remarkable change compared with (a) without gas injection. 
は，混合時間が安定して得られづ，かつ混合に長時問を 要した。これは発泡了ルミナが筧排中に破挽され，けに 浸み込んでいた KCI が溶出して，トレーサー岕答曲線 を乱すためであつた。そこで本失駼は，現場条件とは Table 1 で後述する相似性がやや異なるけ机ども，回転 速度 $20 \mathrm{rpm}$, 浸漬深さが 15 扰よび $28 \mathrm{~cm}$ の 2 水準に ついて実施した．ガス流量は $0 \sim 10 \mathrm{Nl} / \mathrm{min}$ の籁用で変 え, 所定浸漬深さにおいてそれぞれ 3 回の測定を行なっ た.こうして得られた混合時間をガス流量に対して示せ ば, Fig. 5 のようである。これより, 混合時間 $\theta$ はガス 流量の増加とともに減少しており, スラグーメタル間の 反応促進のために，ガ不吹き込及併用は効果があるとい える.この傾向は, インペラーの回転速度が大となり， 浸漬深さが浅くなっても, 変わらず維持されるとして大 過なから5。

\section{3 フロー・パターンの観察}

ガス吹き込みを併用することにより，脱硫剤は溶銑中 に激しく分散し, 脱硫反応を促進するものと考兄られる. この効果を実際に確認するため, フロー・・ターンの観 察を行なつた.

Photo. 1 は脱硫涬を想定した着色流動パラフィンの 水中への分散状況を示している.インペラー回転速度は $80 \mathrm{rpm}$ であり，ガス流早が 0 と $30 \mathrm{Nl} / \mathrm{min}$ の場合を 比較して示している. 使用したインペラーは Fig. 2 よ り大型で, 大径(Fig. 2 の a) $240 \mathrm{~mm}$, 㩭汼素子径 (Fig. 2 の b ) $18 \mathrm{~mm}$ であり，これを浸漬深さ $5 \mathrm{~cm}$ と比較的
浅い位置にセットして回転した. Photo. 1より明らかな

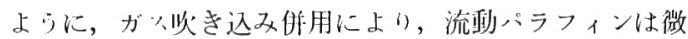
細な滴となり，ガス炊き込みの䑤い時よりも推い水中に まで分散しており，予期した效果が明らかに浔められる。 つぎ，Fig. 2 のインペラーを水中深く浸漬（浸漬深 さ 20 および $29 \mathrm{~cm}$ ) して, 回転速度 $61.5 \mathrm{rpm}$ で実験 した. ガス流量は 0.5 および $10 \mathrm{Nl} / \mathrm{min}$ と逐次変えて， 脱硫剂もしくは脱硫㳯の分散状況を観察した. 結果を Photo. 2 ( a )，(b) に示寸，Photo. 2-aは脱硫㳯にみ たてて着色流動パラフィンを用いた場合である。インペ ラーの回転により浴面は凹状を呈し，その凹み部に流動 パラフィンがコーン状に凝集する.ガス吹き込みのない 場合, このコーンは安定に存在し, 水中への流動パラフ ィンの分散は汪とんど観察されない.ところが，ガス流 量を $5,10 \mathrm{Nl} / \mathrm{min}$ と増していくと, ガスの浮上に伴い ユーン部が翼乱され, 脱硫剂が分散していく様子が明瞭 である・

同様に, Photo. 2 ( b ) は脱硫剂として発泡アルミナを 使用した場合である・ガス吹き込みのない場合には,イン ペラー軸部に円柱状に集積しているマルミナが，ガス吹 きに伴つて円周方向一分散していく様子が明瞭である.

これらの観察結果より，ガス吹き込みを併用したイン ペラー法は, 脱硫剂の溶銑中一の分散化に効果があり, 脱硫反応は促進されるものと推論される。

\section{4 モデル実験の総括}

上述のモデル実験から得られた知見をまとめれば， (a)

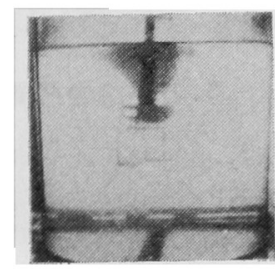

ONI/min

(b)

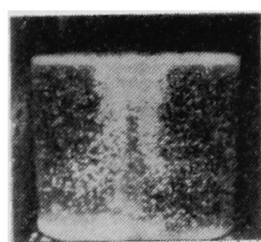

ONL/min

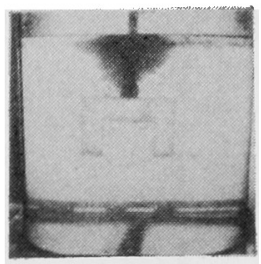

$5 \mathrm{Nl} / \mathrm{min}$

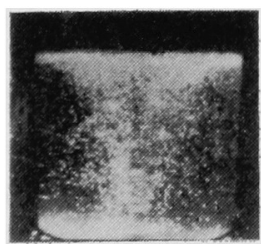

$10 \mathrm{NI} / \mathrm{min}$

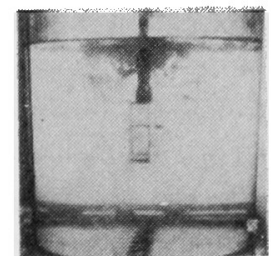

$10 \mathrm{~N} / \mathrm{min}$

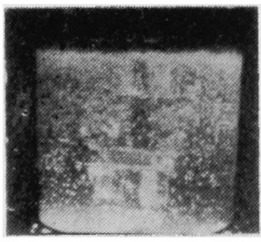

$30 \mathrm{NI} / \mathrm{min}$

Photo. 2. Influence of gas injection on the dispersion of slag agents into the water stirred by the impeller; (a) liquid paraffin is used and the immersion depth of the impeller is $20 \mathrm{~cm}$ and the revolution rate is $61.5 \mathrm{rpm}$, (b) hollow alumina balls are used and the immersion depth is $29 \mathrm{~cm}$ and revolution rate is $61.5 \mathrm{rpm}$. 
Table 1. Comparison of dimensionless parameters between the water model and the actual plant.

\begin{tabular}{|c|c|c|c|c|c|c|c|c|}
\hline \multirow{3}{*}{$\underset{(\mathrm{rpm})}{\text { Revolution rate }}$} & \multicolumn{4}{|c|}{ Water model } & \multicolumn{4}{|c|}{ Hot metal } \\
\hline & $N_{R c}$ & $N_{F r}$ & $N_{F r}^{\prime}$ & $N_{F r}^{\prime}$ & $N_{R e}$ & $N_{F r}$ & $N_{F r}^{\prime}$ & $N_{F r}^{\prime}$ \\
\hline & Water & Water & $\begin{array}{l}\text { Water- } \\
\text { paraffin }\end{array}$ & $\begin{array}{l}\text { Water- } \\
\text { alumina }\end{array}$ & Hot metal & Hot metal & $\begin{array}{l}\text { Hot metal- } \\
\quad \text { slag }\end{array}$ & $\mid \begin{array}{c}\text { Hot metal- } \\
\mathrm{CaC}_{2}\end{array}$ \\
\hline 20 & $8.8 \times 10^{3}$ & 0.029 & 0.316 & 0.581 & $3.7 \times 10^{5}$ & 0.146 & 0.238 & 0.219 \\
\hline 40 & $1.8 \times 10^{4}$ & 0.117 & 1.267 & 2.330 & $7.4 \times 10^{5}$ & 0.583 & 0.952 & 0.874 \\
\hline 60 & $2.7 \times 10^{4}$ & 0.264 & 2.846 & 5.237 & $1.1 \times 10^{6}$ & 1.309 & 2.140 & 1.965 \\
\hline 80 & $3.5 \times 10^{4}$ & 0.465 & 5.057 & 9.305 & $1.5 \times 10^{6}$ & 2.326 & 3.803 & 3.491 \\
\hline 100 & $4.4 \times 10^{4}$ & 0.728 & 7.909 & 14.55 & $1.9 \times 10^{6}$ & 3.638 & 5.948 & 5.460 \\
\hline
\end{tabular}

$N_{R e}:$ Reynolds number, $N_{F r}:$ Froude number, $N_{F r}^{\prime}:$ Modified Froude number

(1) 液バルクの均一混合時間はインペラーの攪抖ェ ネルギーだけで十分であり，ガス吹き込みによる改善効 果は小さかつた.

（2）しかし脱硫剤にみたてた発泡アルミナにトレー サーを浸み込ませて行なつた実験結果によれば，スラク ーメタル間の物質移動はガス吹き込み併用により加速さ れ,

（3）その主な理由が，ガス吹き込み併用により脱硫 剂が浴中に溦細かつ激しく分散することによる， などが明らかとなつた。

モデル実験の知見が，実機にも正しく反映されるため には，その現象を支配する無次元数が両者間でほぼ同じ 值でなければならない，本系の場合相似条件を規定する のに, 次の 3 つの無次元数が重要と思われる.

$$
\begin{aligned}
& N_{R e}=\rho L V / \mu \ldots \ldots \ldots \ldots \ldots \ldots \ldots \ldots \ldots \ldots \ldots \ldots \ldots \ldots \ldots \\
& N_{F r}=V^{2} / g L \ldots \ldots \ldots \ldots \ldots \\
& N^{\prime}{ }_{F}=\rho_{s} V^{2} /\left[\left(\rho-\rho_{s}\right) g L\right]
\end{aligned}
$$

ここに， $N_{R \ell}, N_{F r}$ および $N_{F r}^{\prime}$ はそれぞれレイノルズ 数，フルード数拈よび修正フルード数である. $\rho, \rho_{s}$ は それぞれ溶銑と脱硫剤密度，Vはインペラーの周速度， $\mu$ は溶銑の粘度， $L$ は装置代表長さ，および $g$ は重力加 速度である。

本モデルが実機の約 $1 / 5$ のサイズであることを考虑し て，インペラー回転速度が 20〜100 rpm の範囲で（1） 〜 (3) 式の無次元数を試算すれば, Table 1 の值を得 る.

これより水モデルでの $N_{R e}$ はおおむね 104 のオーダ であるのに対して，実機のそれは $10^{6}$ と約 2 桁大きい。 しかし $N_{R e}$ が $10^{4}$ を越えると，流れにおよぼす粘性の 影響が無視され 慣性力だけに支配されるようになるの で，流れのパターンはモデルと実機でかなり類似してい
るといえる．つぎにフルード数 $\left(N_{F r}\right)$ ではモデルと実 機で一桁の違いがあるが，スラグーメタル間の混合を想 定する場合には，修正フルード数 $\left(N^{\prime}{ }_{F r}\right)$ ，すなわち，浴 中に分散したスラグの慣性力と浮力の比の方が重要な役 割を果たすであろら. Table 1 より水一流動パラフィン、 水一発泡了ルミナ間の $N^{\prime}{ }_{F r}$ は溶銑-スラグ, 溶銑 $-\mathrm{CaC}_{2}$ 間の $N^{\prime}{ }_{F r}$ とほぼ同じ値を示す. したがって，本モデル 実験で観察されたガス吹き込みによるエルマルジョン促 進現象は実機でも同様に期待される.

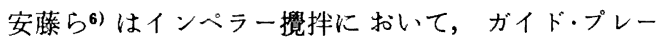
トを設け回転シャフト周りの渦に巻き込まれた脱硫剤の 分散を強化することができたと報告しているが，これも インペラー単独の定常流に 翼乱を与光，スラク゚ーメタル 間のエマルジョンを強化した先例といえる.

\section{3. 実機の概要と脱硫性能}

ここでは，上述のモデル実験の知見を踏まえて設計さ れた実機 NP プロセスの概要を述べ，つついて本装置 の脱硫性能を明らかにする.

\subsection{NP プロセスの概要}

NP 式脱硫装置の組立概略図を Fig. 6 に示寸. 窒素 ガスはロータリー・ジョイントを介してシャフト部を貫 通する管路に供給され，2 分されてインペラー先端部の 開孔部から浴中へ放出される. シャフト全長は 4400 $\mathrm{mm}$, シャフト径は $140 \mathrm{~mm}$ である. ベベルギヤは回 転駆動力をシャフトに伝達する働きをし，インペラー上 部には防熱板がとりつけられている.

Photo. 3 はインペラーの一例を示している.これは $60 \mathrm{t}$ 溶銑鍋を対象にしたもので, 取鍋内径 $2600 \mathrm{~mm}$ に 対してインペラー径は $840 \mathrm{~mm}$, 脚の長さは $650 \mathrm{~mm}$ で ある.インペラー両端には $25 \mathrm{~mm} \phi$ の吹き込み口があ 


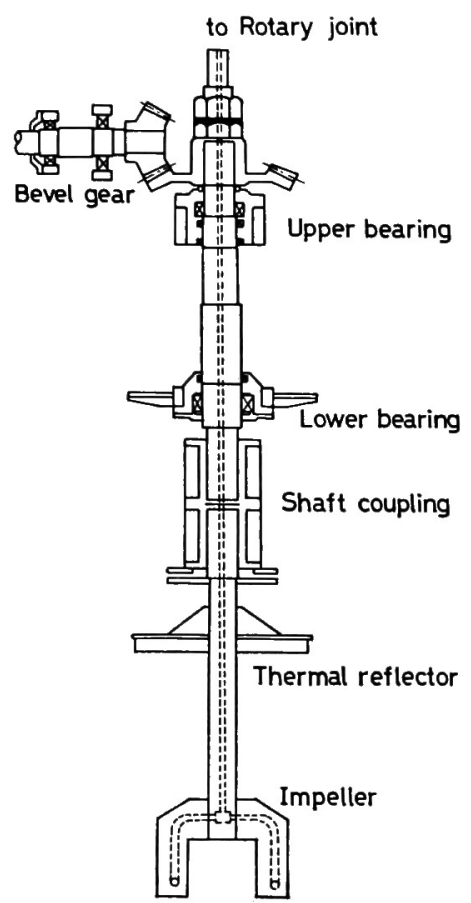

Fig. 6. A schematic view of the NP impeller used in the plant scale equipment.

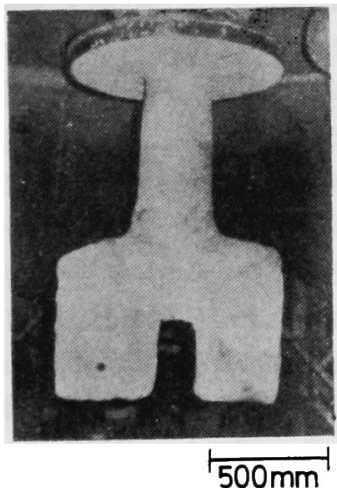

Photo. 3. NP impeller used in the plant scale equipment; the opening for the gas injection is visible at the end of the left leg.

り,ここから回転方向と逆向きに, $3 \sim 4 \mathrm{Nm}^{3} / \min$ の $\mathrm{N}_{2}$ ガスを浴面下 $400 \mathrm{~mm}$ の位置で吹き込む.

インペラーは芯部が鉄骨からなり，その周囲にアルミ ナ系プラスチック耐火物を張りつけてある. 脱硫処理中 インペラー回転速度は $77 \mathrm{rpm}$ で肩部が浴面から露出寸 る程度に浸漬する.

\section{2 脱硫処理条件}

実操業に打ける処理条件をまとめれば以下のとおりで
ある. 取鍋内溶銑话は 60〜70 $\mathrm{t}$ であり，その平均組成 は $4.5 \% \mathrm{C} ， 0.5 \% \mathrm{Si}, 0.5 \% \mathrm{Mn}$ である. 溶銧温度は処 理前が 1360 土 $40^{\circ} \mathrm{C}$ ，また 10 から $12 \mathrm{~min}$ の処理によ り約 $10 \sim 20^{\circ} \mathrm{C}$ の盜度降下がある. 脱硫剂として使用し た工業用カルシウム・カーバイド（以下カーパイドと略 記）は粒径が $0.5 \sim 3.0 \mathrm{~mm}$ の範囲にあり，純度は 75 $\% \mathrm{CaC}_{2}$ である。 また $5 \%$ の $\mathrm{CaF}_{2}$ をフラックス成分と して含んでいる. 少量の $\mathrm{CaF}_{2}$ の混入が $\mathrm{CaC}_{2}$ の反応効 率を向上するのに有效なことは，すでに著者らが報告し だ).

すでに基礎実験から明らかなように7)，高炉スラグの 混入はカーハィドの脱硫能を著しく低下させる原因とな るので，脱硫処理前にはかき出し式除涬機による徽底し た取鍋排澾を行なつている。なお $\mathrm{S}$ の分析は燃焼容量法 によつた.

\section{$3 \cdot 3$ 脱硫実績}

脱硫性能を定量的に表わすために以下の 2 量を定義す る.すなわち，カーバイド利用効率，クと脱硫率， $\mathrm{S}_{y}$ で ある、クは使用したカーバイド中何\%の $\mathrm{CaC}_{2}$ が溶銑 S と反応したかを示し，また $\mathrm{S}_{y}$ は初期濃度， $\mathrm{S}_{0}(\%)$ の中何\%が除去されたかを示す。これらはカーバイト

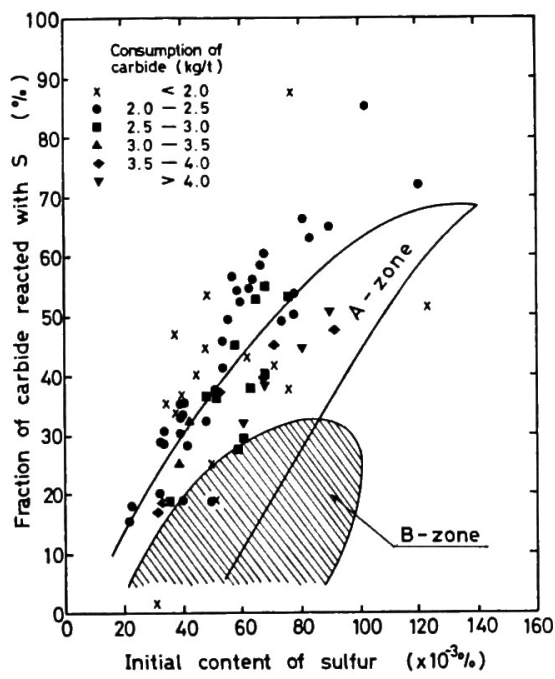

Fig. 7. Influence of the initial,content of sulfur on the chemical efficiency of calcium carbide for the NP process applied after deslagging the BF slag. Though the actual data are not reproduced here, two extreme cases are depicted by zones $\mathrm{A}$ and $\mathrm{B}$; the former corresponds to the NP process with the BF slag and the latter the NP process with the $\mathrm{BF}$ slag and without the injection of nitrogen gas. 
原単位を $w_{\mathrm{CaC}_{2}}(\mathrm{~kg} / \mathrm{t})$, 脱硫後 $\mathrm{S}$ 浱度を $\mathrm{S}_{f}(\%)$ とし て，てれぞれ（4)，(5) 武で少光られる。

$$
\begin{aligned}
\eta & =100\left(\mathrm{~S}_{o}-\mathrm{S}_{f}\right) /\left(0.75 w_{\mathrm{CaC}_{2}} / 20\right) \\
\mathrm{S}_{y} & =100\left(1-\mathrm{S}_{f} / \mathrm{S}_{o}\right) \ldots \ldots \ldots \ldots \ldots \ldots \ldots \ldots \ldots \ldots \ldots
\end{aligned}
$$

$\mathrm{NP}$ 法によるカーバイト利用効率と初期 $\mathrm{S}$ 濃度の関係 を，カーバイド原単位で層別して示せば Fig. 7 のよう である. 図には比較のためにゾーン A および B を示し た.ゾーン A は高炉スラグの存在下で NP 法を適用し た場合に，またゾーンBは高炉スラグが存在し，しかも ガス吹き込みを夹施しない単純門型インペラーの場合 に，それぞれ対応する。

これより，たとえばカーバイド原単位が $3.0 \mathrm{~kg} / \mathrm{t}$, 初期 S 濃度が $0.05 \%$ の場合, カーバイド利用効率の平 均值は, 排涬後 NP 法で 35\%, ゾーンAの NP 法で 25\%，またゾーンBの単純門型インペラー法で $20 \%$ で ある. 初期 $\mathrm{S}$ 濃度, カーバイド原単位が等しい条件下で は，排涬後 NP 法を適用した場合にカーバイド利用効 率は最も高く, 以下高炉スラグ存在下の NP 法, 門型 インペラーの順に下降していく.

Fig. 7 のP 法のデータについて, 今一つの脱硫性 能パラメータ, $\mathrm{S}_{y}$ とカーバイド原単位の関係をみれば Fig. 8 を得る.ここに, 各プロットは初期 S 濃度で層別 した. 当然のことながら, カーハイド原単位の増加とと もに，脱硫率 $\mathrm{S}_{\mathrm{y}}$ は向上する.ささと同一条件，すなわ ちカーバイド原単位 $3 \mathrm{~kg} / \mathrm{t}$, 初期 $\mathrm{S}$ 濃度 $0.05 \%$ とす れば, NP 法の $\mathrm{S}_{y}$ は 76\% となるのに対し，ゾーン $\mathrm{A}$ のヒートでは 56\%，ゾーンB のそれは 40\% と低下す る.なお上記条件の下で NP 法の脱硫後 $\mathrm{S}$ 濃度は 0.012 $\%$ に相当する.

カーパイド原単位をさらに増し $5 \mathrm{~kg} / \mathrm{t}$ として初期 $\mathrm{S}$ 濃度 $0.05 \%$ の溶銑に NP 法を適用与れは， $\mathrm{S}$ 濃度は $0.002 \%$ に低下し，カーハイイド利用効率は $26 \%$ ，脱硫 率は 96\%となる.

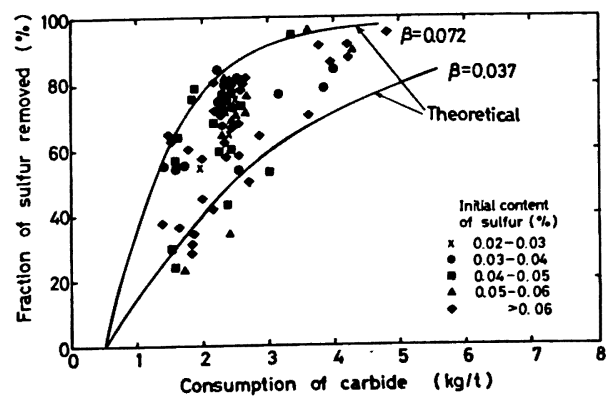

Fig. 8. Relationship between amount of calcium carbide used and fraction of sulfur removed from the bath.

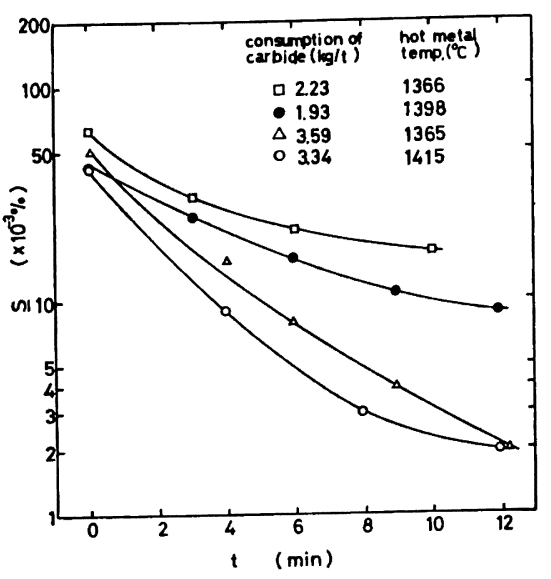

Fig. 9. Typical example of changes of sulfur content during the desulfurization treatment.

NP 法の脱硫速度を定量的に把握するため，16ヒート について処理中も一定間隔でサンプルを採取した.こう して得られた $S$ 濃度経時変化の数例を Fig. 9 に示す.

\section{4. 脱硫反応速度について}

\section{$4 \cdot 1$ 従来の研究}

本章では NP 法によつて得られた脱硫速度の律速段 階について検討寸る.さててカルシウム・カーバイドによ る溶銑の脱硫反応において，考え水ばならない素過程は 次の 3 つである.

(1) 溶銑側境膜内の $\mathrm{S}$ の移動

(2) 反応界面に拈ける $\mathrm{CaS}$ 生成の化学反応

(3) 反応生成物層中の $\mathrm{S}$ あるいは $\mathrm{Ca}$ イオンの移動

大井ら ${ }^{8)}$ はブロックから切り出した円柱カルシウム・ カーパイドを溶銑中に浸漬回転させ脱硫速度を調べた. その結果，上記の素過程(1)が律速となり脱硫が進行する と結論つけけいる. 成田らの GMR 法の結果1) 女大井 らの結論と矛盾しないとしている. 塩見ら9)は，粉末力 ルシウム・カーパイドを用いて，小型ロッキング炉によ る溶銑の脱硫速度を調べ，その結果が素過程(1)あるい (2)を律速段階として説明でき，どちらとも断定できない と報告している.

一方，不破によれば10)，溶銑中に浸漬したカルシウム・ カーバイドをいったん引き上げ微視的に調べると, 表面 から内部一順に $\mathrm{CaS}$ 層, キッシュ黒鉛層, $\mathrm{CaO}$ 層, 力 一ボン偏析層および $\mathrm{CaC}_{2}$ 層となっており, キッシュ 黑鉛層は溶銑の冷却に伴って析出したものであること, $\mathrm{CaO}$ 層は浸漬前の $\mathrm{CaC}_{2}$ 表面の高温酸化によつて生成 したものであること，またカーボン偏析㬝は Ca イオン 
が反応面に移動して取り残されて生成したものであるこ となどを指摘している. その結果不破は, 上記素過程(3) が脱硫速度に強い影響を与えるはずと主張している.

高田ら゙は粒状カルシウム・カーバイドによる溶銑の 脱硫を黒鉛製インペラーを用いて実験室的に行なつた。 その際溶銑温度を $1400^{\circ} \mathrm{C}$ と一定に保持し， C 濃度を 3,4 および $4.8 \%$ と 3 段階に変えてみたところ, 脱硫 は $\mathrm{C}$ 濃度が低いほど速く進行した。この事実は液側の物 質移動律速とは矛盾するものであり, 素過程(2)化学反 応律速を考虑せ权ば説明できない。

以上見てきたように，粒状カルシウム・カーバイトに よる溶銑の脱硫反応の律速段階が，上記素過程(1)〜 (3)の 中, どれであるかについて統一的見解は示されていない． とくに，今回のごとく粒状カルシウム・カーバイドを用 いた現場実験においては, 㩭拌の強化に伴つて, 液側 $\mathrm{S}$ の物質移動を促進する効果とモデル実験でみたように, 脱硫剤の溶銑中への分散による界面積増大効果が重畳す る. しかも摫找エネルギーは $\mathrm{CaC}_{2}$ 表面から反応の抵 抗となる $\mathrm{CaS}$ 層を取り去る効果も無視し得ない。した かって，靦䢁に伴い脱硫速度が增大寸るからといって， それが上記素過程(1)〜(3からいずれかを取唅避択する根 拠とはなり得ない。

\section{$4.2 N P$ 法の律速段階}

ここでは上に述べた従来の研究結果を踏まえつつ, NP 法の脱硫反応の律速段階について考察する.

まず，実験事実として，もつとも重視しなければなら ないのは, 初期 $\mathrm{S}$ 濃度が高い程, カーバイド利用効率が 高い(Fig. 7) といらことである. 従来の研究ではここ の点に関する考虑が十分でなかつた。るしる応生成物 $\mathrm{CaS}$ 層中の物質移動が律速となつて脱硫反応が進行す るのであれば, 初期 $\mathrm{S}$ 濃度によらない一定のカーバイド 利用効率が得られるはずである。したがつて先の素過程 (3は NP 法の律速段階の主体とはならない。

$\mathrm{CaS}$ 中の $\mathrm{S}$ の拡散は, 例えば塩見ら9)が $\mathrm{NiS}$ 中の $\mathrm{S}$ の扗散係数から類推しているように，溶銑中のそれに比 較して約 2 析む小さく, 不破10)の指摘にもあるよ5に， これが律速段階とならないのは一見不思議である。これ について著者らは次のように考える、 $\mathrm{CaC}_{2}$ および $\mathrm{CaS}$ の室温における分子容は，それぞれ $28.8 \mathrm{~cm}^{3}$ 拈よび $32.0 \mathrm{~cm}^{3}$ と与えられる11). したがって $\mathrm{CaS}$ の生成に伴 つて $\mathrm{CaC}_{2}$ の格子は膨張しつつ変化することになる.

つまり $\mathrm{CaC}_{2}$ から成る半径 $a$ の球が $\mathrm{S}$ と反応して, その まま半径 $a$ の球体を維持し, かつ内部に反応生成物の $\mathrm{C}$ (分子容 $5.3 \mathrm{~cm}^{3}$ )をも取り込んでいるとすると, $\mathrm{CaS}$ の 格子は $45 \%$ もの収縮状態となる。したがつて $\mathrm{CaC}_{2}$ の
表面に生成した $\mathrm{CaS}$ は格子膨張により $\mathrm{CaC}_{2}$ 表面から

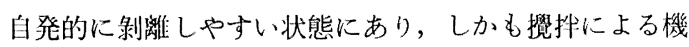
椷的エネルギーがあるので，反応生成物は容易に取り除 かれるであろう。

素過程(3では説明できない今一つの実験事実を挙げれ ば，同じ初期 S 濃度でみ札ば，カーバイト原単位が少な いほど，カーバイド利用効率が向上することである。素 過程(3が律速であ机ば，カーバイド原単位によらず，カ 一バィド利用効率は一定でなければならない,一方, 素 過程(1) と(2)の場合には，後述するように上記実験事实と 矛盾しない。

素過程(1)と(2)どちらかが律速となつて脱硫が進む場 合, 脱硫速度式は形式的に（6）式で書ける.

$$
-d \mathrm{~S} / d t=k A \mathrm{~S} / V=K \mathrm{~S}
$$

ここに, $\mathrm{S}$ は溶銑 $\mathrm{S}$ 濃度 $(\%), A$ は反応界面積 $\left(\mathrm{cm}^{2}\right), V$ は浴の体積 $\left(\mathrm{cm}^{3}\right), k$ は物質移動係数拈よび $K$ は反応速 度定数である.

さて, $\mathrm{S}$ 濃度が時間の指数関数となる $(6)$ 式の関係は Fig. 9 の数例にみるように, 脱硫開始後 $6 \mathrm{~min}$ までは よく成立しているが，それ以降では直線の勾配が緩くな り，カーバイド粒同志の接着による反応界面積の減少， あるいは $\mathrm{CaS}$ 層内の物質移動律速などの可能性が生じ てくる. しかし脱硫開始後 6 min までの間に, 約 $80 \%$ の $\mathrm{S} か ゙$ 除去されており，NP 法における大部分の脱硫が 素過程(1)と(2)のいず机かに律速されて進むと考えて問題 なかろう。

そこて，先に脱硫速度を調べた 16 ヒートの脱硫開始 後 6 min までの実測值から (6) 式が成り立つとして, $K$ および $k$ 值を算出した。 ここに, 溶銧密度, $6.9 \mathrm{~g}$ $\mathrm{cm}^{-3}$, カーバイド密度 $2 \mathrm{~g} \mathrm{~cm}^{-3}$, 反応界面積 $A$ は, 暫定 的に, 平均粒径 $1 \mathrm{~mm}$ のカーバイドが凝集せずに一様に 溶銑中に分散しているものと仮定して算出した。こうし て得られた $k$ 值の温度依存性をみたのが Fig. 10 である これより最小 2 乘法で求めた見掛けの活性化ェネルギ 一Eは $24.1 \mathrm{kcal} / \mathrm{mol}$ であつた.この値は化学反応の活

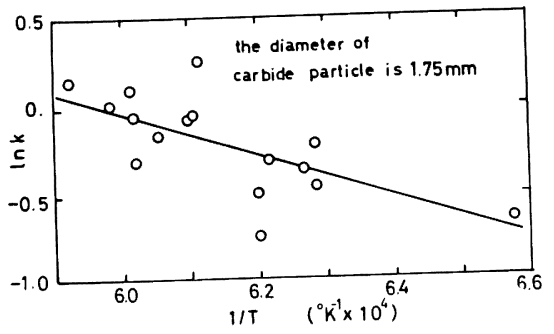

Fig. 10. Influence of temperature on the mass transfer coefficient of desulfurization. 
Table 2. Rate constants and mass transfer coefficients obtained by the various investigators for the desulfurization reaction of hot metal with calcium carbide.

\begin{tabular}{|c|c|c|c|c|c|c|c|c|}
\hline & \multicolumn{3}{|c|}{ Oor, et al.8) } & \multicolumn{2}{|c|}{ NARITA, et al.1) } & \multicolumn{3}{|c|}{ This work } \\
\hline$K\left(\min ^{-1}\right)$ & & & & \multicolumn{2}{|c|}{0.30} & \multicolumn{3}{|c|}{$0.16 \sim 0.33$} \\
\hline & \multicolumn{3}{|c|}{ Revolution rate (rpm) } & \multicolumn{2}{|c|}{$\mathrm{CaC}_{2}$ diam. $(\mathrm{cm})$} & \multicolumn{3}{|c|}{$\mathrm{CaC}_{2}$ diam. (cm) } \\
\hline \multirow[t]{2}{*}{$k\left(\mathrm{~cm} \cdot \min ^{-1}\right)$} & 100 & 200 & 300 & 0.05 & 0.10 & 0.05 & 0.10 & 0.175 \\
\hline & $0.06 \sim 0$. & $0 \sim 0$. & $3 \sim 0.18$ & 0.125 & 0.25 & \multicolumn{3}{|c|}{$0.24 \sim 0.330 .47 \sim 0.650 .83 \sim 1.15$} \\
\hline
\end{tabular}

性化エネルギーとしては,かなり小さな值のよらである. 本実験で求まつた $K, k$ 值などを従来の研究者らの值 と比較すれば Table 2 のとおりである.これより本実 験の $K$ 值は $0.16 〜 0.33 \mathrm{~min}^{-1}$ と成田らの值) とほぼ等 しい，一方 $K$ 值は他と比べてかなり大きく，NP 法の摫 找効果が現われている.すなわち, $\mathrm{CaC}_{2}$ 回転円柱の回 転速度にして, 300 rpm 以上に相当し, 成田らの值の約 倍の大きさを示す.

上述のように素過程(2)を採るには活性化エネルギーが 小さ過ぎるきらいがある，てこで以下律速段階として素 過程(1)を仮定して, 物質移動係数 $k$ 值について, 理論的 にも矛盾がないか否か考察する.

半径 $r_{e}$ の球形粒子が 溶銑中を速度 $v$ で運動している 時, 粒子表面に到達寸る $\underline{\mathrm{S}}$ の物質移動係数, $k_{B}$ は BAIRD ら

$$
k_{B}=0.82 D^{1 / 2} v^{1 / 2} r_{e}{ }^{-1 / 2}
$$

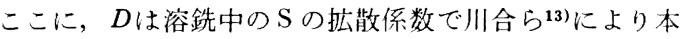
実験温度で $3.0 \times 10^{-5} \mathrm{~cm}^{2} / \mathrm{sec}$ と与えられる。

一力，カーハイト粒の半径と密度が，それぞれ $r_{c}, \rho_{P}$, およびカーバイト使用量が $w$ の時, 反応界面積, $A$ は $3 w / r_{e} \rho_{P}$ で与えられるので，(6) 式の $k$ と $K$ の間には (8) 式の関係が求まる.

$$
k=K \cdot V r_{e} \rho_{P} / 3 w
$$

(7) と $(8)$ を等置して， $r_{e}$ は $(9)$ 式から算出される.

$$
r_{e}=\left(2.46 D^{1 / 2} v^{1 / 2} w / K V \rho_{P}\right)^{2 / 3}
$$

またカーバイド粒子の接着個数 $n$, および接着による反 応界面積の減少率 $\beta$ は初期半径を $r$ とおけば，それぞれ (10)，(11) 式となる.

$$
\begin{aligned}
& n=\left(r_{e} / r\right)^{3} \\
& \beta=\left(r / r_{e}\right)
\end{aligned}
$$

そこで，vはインペラーの周速度， $338 \mathrm{~cm} / \mathrm{sec}$ と打け ば $r_{\varepsilon}, k_{c}, n$ および $\beta$ などは Table 3 のような值をと る.ここにカーバイドの初期半径 た.これより, NP 法では, 約 2700 個の粒子が接着し, 平均径 $1.3 \mathrm{~cm}$ の粒子になつているとすれば, 液側 $\mathrm{S} の$
Table 3. Computed values of the rate parameters for the desulfurization of hot metal by the NP process.

\begin{tabular}{l|c|c|c|c|c|c}
\hline $\begin{array}{c}\text { Symbol } \\
\text { dimension }\end{array}$ & $K$ & $r$ & $r_{\varepsilon}$ & $k_{c}$ & $n$ & $\beta$ \\
\cline { 2 - 7 } & $\mathrm{min}-1$ & $\mathrm{~cm}$ & $\mathrm{~cm}$ & $\begin{array}{c}\mathrm{cm} / \\
\mathrm{min}\end{array}$ & $\begin{array}{c}\text { num- } \\
\text { ber }\end{array}$ & $\%$ \\
\hline $\begin{array}{c}\text { Computed } \\
\text { values }\end{array}$ & 0.245 & 0.05 & 0.575 & 6.54 & 1521 & 8.7 \\
\hline
\end{tabular}

物質移動係数は実測值と理論值でよい一致を示す．NP 法におけるカーバイドは処理前に一括して添加される. 処理中の浴面を钼察すると，3〜 $5 \mathrm{~cm}$ といつた塊状スラ グを見つけることもまれではないので，上述のカーバィ ド粒径 $1.3 \mathrm{~cm}$ はそれほど不合理な值ではない。結局 NP 法の脱硫速度を素過程(1)で律速されるとして，何ら 矛盾はなく，実験事実をもつともよく説明できることが 明らかとなつた。

いま(6)式を積分し（7)〜（9) 式を用いて $r_{e}$ を消去 し, かつカーバイド原単位 $w_{\mathrm{CaC}_{2}}(\mathrm{~kg} / \mathrm{t})$ が $w / V$ に比 例することを考虑すれば，(12)式を得る。

$$
\mathrm{S}=\mathrm{S}_{o} \exp \left[-7.533 \times 10^{-2} \beta^{3 / 2} w_{\mathrm{CaC}_{2}} t\right]
$$

ここに， $\mathrm{S}_{o}$ は初期 $\mathrm{S}$ 濃度 $(\%) ， w_{\mathrm{CaC}_{2}}$ はカーバイド原 単位 $(\mathrm{kg} / \mathrm{t})$, および $t$ は脱硫時間 $(\mathrm{sec})$ である.

$\mathrm{NP}$ 法の平均処理時間は $11 \mathrm{~min}$ であるので，(4), (5) 技よび(12)式より脱硫率 $\mathrm{S}_{y}$ とカーバイド利用効率 クは(13)，(14)式で与えられる.

$$
\begin{gathered}
\mathrm{S}_{y}=100\left(1-\exp \left(-49.72 \beta^{3 / 2} w_{\mathrm{CaC}_{2}}\right)\right) \\
\eta=26.67 \mathrm{~S}_{o} \cdot \mathrm{S}_{y} / w_{\mathrm{CaC}_{2}} \cdots \ldots \ldots \ldots \ldots \ldots \ldots \ldots \ldots \ldots \ldots
\end{gathered}
$$

これらの式は先に述べた実験事実と矛盾しない。すな わち， $\mathrm{S}_{o}$ が大ほどクは大となり，また $\mathrm{S}_{o}$ が一定の時， $w_{\mathrm{CaC}_{2}}$ が小さいほどクは增大する. Fig. 8 には $\beta$ をパラ ィータとして(13)式の関係を示した。この際(13)式は原 点を通るべきであるが，できるだけせまい幅の $\beta$ 值で実 测值と理論值を一致させるべく横軸のプラス側へややず らした。これは基本となつた（6)式に拈いて，使用した カーバイドの一部が脱硫に寄与しない不純物であること 
を考慮すれば当然予期されるシフトといえる，しかし奏 際にはこの不純物が個々のカーバイド粒の中に均一に混 入している場合の方が多いので，(6)式で定量的に取り 込むことは困難であろう．Fig. 8 の個々のヒートは高 欧スラグの除去の程度，処理温度に違いがある。これら は, 速度論的には， $\beta$ の変動要因になるものと考えられ る. そして Fig. 8 より NP 法での $\beta$ 值は, 実験条件に 応じて， 0.04 から 0.07 の䉜囲で変化するものと理解 される。

\section{5. 結}

\section{$\overline{\overline{\bar{D}}}$}

取鍋用溶銑脱硫装置として，当社が開発した NP プ ロ七スについて，混合の特傜を水モデル実験により明ら かにした。この結果を踏まえて実機を製作し，現場に適 用した漈の脱硫性能を調べた，得られた結果を速度論的 に解析し，脱硫反応の律速段階を推定した。

得られた結論は以下のとおりである。

1) コールド・モデル実験において，トレーサー法によ り調べた溶銑中の均一混合時間は,インペラーの単独擤 找でも十分速く，ガス吹き込又有無の影響は小さかつた。

2）一方，スラグー溶銑間の物質移動を伴うトレーサ 一の均一混合時間は,ガス吹き込み併用により短縮され， スラグーメタル間の反応促進に効果のあることが明らか となつた。

3) また，脱硫剤に見立てた流動パラフィンあるいは 発泡アルミナの水中一の分散状態の肉腿観察によれば, ガス吹き込み併用により, 脱硫剤は溶銑中に激しく分散 し，脱硫反応促進に効果のあることが明暸であつた.

4) $60 \mathrm{t}$ 取鍋溶銑を対象に製作した実機 NP では, カーハイド原単位 $3 \mathrm{~kg} / \mathrm{t}$, 初期 $\mathrm{S}$ 濃度 $0.05 \%$ の条件 でカーハイド利用効率 34\%, 脱硫率 76\% の実績を示し た、またガス吹き込みによる脱硫性能の向上も明らかと なつた。

5）脱硫が 1 次反応式に従つて進行する領域につい て, 実験的に求めた物質移動係数の見掛けの活性エネル ギーは $24.1 \mathrm{kcal} / \mathrm{mol}$ であり, 物質移動係数として 0.24 $\sim 1.15 \mathrm{~cm} / \mathrm{min}$ なる值を得た. また反応速度定数とし
ては 0.16〜0.33 $\mathrm{min}^{-1}$ なる值を得た。

6) 脱硫反応の律速段階は溶銑側境膜中の $\mathrm{S}$ の払散に あると結論した。

7)この時脱硫剤として一括投入した粒状（0.5-3.0 $\mathrm{mm} \phi)$ のカルシウム・カーバイドは, 約 $1.3 \mathrm{~cm}$ 径の塊 状スラグとなつて，溶銑中に一様分散するものと推論さ れた。

本研究の遂行に当り協力いたたいた以下の方々に深く 感謝します. 技術研究所製鋼研究室仲村研究員, 千葉製 鉄所製鋼部今井課長，同数土掛長，同柿元，石坂両技師， 千葉製鉄所設備技術室丹野掛長. また討論に参加され贵 重な意見を述べられた技術研究所企画室岡部室長並びに 本研究の発表を許可された技術研究所長三本木専務に厚 く感謝いたします。

\section{交献}

1) 成田責一, 佐藤義智, 森隆資, 伊藤孝道, 久次 米章: 鉄と鋼, 62 (1976), p. 962

$2)$ H. KajIOKA: McMaster University Conference Proceedings, W. K. Lu, Editor, 1975

3 ) $F$. Kramer, $J$. Motz and $K$. Röhig: Giesserei, 55 (1968), p. 149

4 ) $W$. Meichsner, $K . H$. Peters, $W$. Ullrich, and H. KNaHL: J. Metals, 26 (1974), p. 55

5 ) $H$. Kramers, G. M. BaARs and $W . H$. Knoll: Chem. Eng. Sci., 2 (1953), p. 35

6 ) $R$. Ando and T. Kamoshida: Trans. ISIJ, 15 (1975), p. 606

7 ) 的田至康, 中西恭二, 仲村秀夫, 江島涁夫：鉄と 锏, 63 (1977), S.118

8 ) 大井浩, 小口征桨, 南参: 鉄と鋼, 56(1970), p. 3

9）塩見純雄，佐野信雄，松下幸雄：鉄と鋼，56 (1970), p. 14

10) 不破祜：私信 1977 年 10 月

11) J. Chipman : Basic Open Hearth Steelmaking, ed. by G. Derge, (1964), p. 539 [AIME]

12) $M$. Baird and $J$. Davidson: Chem. Eng. Sci. 19 (1962), p. 87-93

13）井上道雄，森 一美：溶鉄·溶滓の物性值便覧(斎 藤恒三編)，(1971)，p. 103 [日本鉄鋼協会] 